BIJDRAGEN TOT DE KENNIS DER FAUNA VAN CURAÇAO.

Resultaten eener Reis van Dr. C. J. VAN DER HORST in 1920.

\title{
NARRATIVE OF THE VOYAGE AND SHORT DESCRIPTION OF LOCALITIES
}

\author{
BY \\ C. J. VAN DER HORST \\ Zoological Laboratory of the University of Amsterdam.
}

(With nine textfigures and two Plates).

\section{INTROD UCTION.}

It was in the spring of 1920 that, especially through the kind co-operation of Prof. SLuiter, I was enabled to carry out a long cherished plan of studying and collecting the rich Fauna of tropical seas. As a conservator at the Zoological Museum of Amsterdam I had handled so much material, collected by the Siboga-Expedition in the East-Indies and, while working over the Madreporaria of this Expedition, I examined so many dead corals, that an increasing desire arose in me to study and collect the rich Fauna of tropical seas and to see live corals myself.

After some reflection it became clear that the island of Curaçao was the locality best fitted for my purpose. I had only a short time at my disposal and, as I intended visiting the United States too, I was assigned to the West-Indies. Of all West-Indian islands Curaçao is. within easiest reach of Holland, but there were other and weightier reasons why I picked out this island. The West-Indies have been rather well explored by different Expeditions,. with the exception of the Southern and South-Western part of the Caribbean Sea. In 1884 the "Albatros" visited Willemstad for a week and Dr. JAMES E. BENEDICT and Mr. W. NYE, the naturalists of that Expedition, made extensive collections, while in 1895 Dr. J. Versluys, on board of the yacht "Chazalie", collected at different localities in the Southern part of the Caribbean and spent a.o. one day in the Schottegat near Willemstad. However the short time spent by these two Expeditions in this part of the Caribbean made a more than casual survey of the very rich Fauna impossible. In 1904 and 1905 Dr. J. BoEKE ${ }^{1}$ ) made for the Dutch Government a trip to Curaçao and the other Dutch West-Indian islands to study the fisheries there and he made an extensive collection of fishes, studied and described by Dr. J. METZELAAR ${ }^{2}$ ), as also of crustaceans which have been worked over by Miss RATHBUN ${ }^{3}$ ). It is logical that, owing to the nature of his commission, this collection of Dr. BoEkE bore an onesided character. Thus it remained a desideratum to look for and collect other forms of the Fauna of those waters.

I am greatly indebted to $\mathrm{H}$. Exc. the Dutch Minister of Colonies for the introduction he gave me to the Governor of Curaçao, and also for the facilities granted me for the transport of my outfit.

1) Dr. J. BOEKE. Rapport betreffende een voorloopig onderzoek naar den toestand van de visscherij en de industrie van zeeproducten in de Kolonie Curaçao. Eerste gedeelte. 's Gravenhage. 1907.

2) Dr. J. MetzelaAR. Report on the Fishes, collected by Dr. J. BoekE, in the Dutch West Indies, 1904-1905, with comparative notes on marine fishes of tropical West Afrika. Dr. J. BoEkE. Rapport visscherij Curaçao. Tweede gedeelte. 's Gravenhage. 1919.

3) MARY J. Rathbun. Stalk-eyed Crustaceans of the Dutch West Indies, collected by Dr. J. Boeke, $1904-1905$. Ibidem. Ibidem. 
The zoological outfit was provided by the Zoological Museum of Amsterdam, where also the material, collected by me, has been deposited. The Management of the Royal Dutch West-Indian Mail was kind enough to gratuitously put sufficient space at my disposal for the shipment of said outfit as also for the greater part of my collections on the homeward-voyage, and for which I herewith beg them to accept my cordial thanks.

I spent exactly two months on Curaçao i. e. from March 31 to May 31, 1920. The time was rather short, considering that I had to do all myself, even the soldering of the covers of the oiltins, a job that tock much time, inexperienced as my hands were with such kind of work. Though greatly regretted by me, some restriction in collecting was inevitable. To study the marine Fauna was my purpose, and I collected all I could get hold of. The restriction concerned the landfauna. Yet the Curaçaoan landfauna is of great interest. As has been pointed out by MARTIN ${ }^{1}$ ) Curaçao is an island of recent date. During the Cretaceous it was probably totally submerged. It was lifted above the sealevel as an atoll in the quaternary epoch and was never connected with another island or the mainland of South-America, though the latter is visible to the naked eye on a clear day. Thus the landfauna of Curaçao is of a very recent date; for the greater part the animal inhabitants of the island have found their way hither from Venezuela, but there are exceptions as was pointed out by von BERLEPSCH ${ }^{2}$ ). Several species are known only from Curaçao and the neighbouring islands of Aruba and Bonaire, a.o. even some birds and it is quite possible that there are still more endemic species.

We possess already some information about the animals inhabiting the island of Curaçao. Mention has first to be made of Simons ${ }^{3}$ ), who in his "Beschrijving van het eiland Curaçou” gives an account of the Fauna, curious indeed but of little scientific value. Of great importance however is the knowledge gained by an Expedition that in 1884 and 1885 was undertaken to the Dutch West-Indian colonies under the leadership of Prof. Martin and Prof. SuRingar, both of Leiden. Said Expedition spent a week on Curaçao, during which time the entomologist J. R. H. NeERvoort van DE Poll collected specimens of the local landfauna, for the greater part, of course, insects, but also some vertebrates. Several articles on this collection have appeared in the "Tijdschrift voor Entomologie" and in the "Notes from the Leyden Museum". In his general narrative of the voyage Prof. MarTin also mentions some mammals, birds and other animals inhabiting the island of Curaçao.

But it should be kept in mind that NEERVOORT VAN DE POLL, like myself, collected on Curaçao after a period of prolonged dryness. Save for cactuses, only leafless shrubs covered the arid soil and all animal live seemed wellnigh extinct. But when abundant rain has fallen, the island is in a short time covered with a tapistry of green and flowers. Everywhere, I was told, butterflies hover, and also other insects certainly will not be absent. It is a great desideratum that this island which belongs to the Netherlands since 1634, and which by its favourable situation and splendid port is a centre of international traffic, should faunistically be thoroughly explored. To do so was impossible to me, partly on account of the prolonged dryness, partly on account of the limited time at my disposal. I at once gave up collecting birds, insects and spiders.

The island abounds with hermitcrabs, called soldaatjes (soldiers) by the natives. They hide in day-time, only venturing forth during the night. When I went out in the evening it seemed as if some one was throwing stones at me, but it were only the shells of the hermitcrabs, which let themselves fall from the stony stairs of my abode. On every shrub and between the stones under the shrubs large numbers of snails are to be found everywhere, especially Cerion uva; another species, Tudora megachile, is by far less abundant. They show not a trace of life, but after a short immersion they all revive and come out of their shells. It must be possible for these animals to subsist in this state of would-be death for long periods, for it sometimes does not rain for years at a stretch. Apart from these landsnails there occurs also a freshwater snail, a species of Planorbis, on the plantation "Hato". Here is found the only spring on the island that continuously gives water. This water is let through gutters into open tanks, and it is in these tanks that this snail occurs besides some freshwater plants and insects,

1) K. MARTIN. Bericht über eine Reise nach Niederländisch West-Indien und darauf gegründete Studien. Leiden. 1887.

2) H. v. BerlepsCh. Die Vögel der Insel Curaçao. Canabis Journ. f. Orn. 1892.

3) G. J. Simons. Beschrijving van het eiland Curaçou. Oosterwolde. 1868. 
Here also the only freshwater fish of Curaçao is to be found in large numbers. It was caught and preserved first by NEERVOORT VAN DE POLL and described by VAN LITH DE JEUDE ${ }^{1}$ ) under the name of Poecilia van de polli. However this little fish is not confined to the tanks of Hato only, I found it together with the Planorbis also on the plantation "Santa Barbara". Here is a socalled tanki i. e. a pond, dug into the bed of a temporary watercourse. Most tankis contain still fresh water in the driest period. They are real oases, surrounded as they are by freshly foliated trees and shrubs. The animals of the plantations. especially consisting of goats, go there to drink, birds continuously fly to and fro or take a bath and numerous dragon-flies shoot through the air. A rest near the tanki of "Jan Tiel" was always a pleasant change after a long march though the barren sunscorched wilderniss.

Poecilia van de polli also occurs further in the mudpools near Caracas Bay together with the allied Cyprinodon riverendi. Both fishes may be found as well in fresh as in salt water. This Cyprinodon even seems to be very insensitive to the salinity of the water. It occurs in great numbers in the mudpools near the shore which during the rainy season are filled with fresh water, but will dry up almost completely during the dry time, when they become very salt. Sometimes these fishes occur in very large numbers in the salienjas (saltpans) and they may become so fat that the natives prepare oil of them. Near Beekenburg, an old fortress dating from the time of the Buccaneers, I found a deep mudpool, in which Cyprinodon riverendi was very abundant, together with a little snail, Batillaria minima, which latter also does not seem to mind the salinity of the water. But one day the whole bottom was dotted with dead fishes, I could not find a single live one. A few days later and after a heavy rainfall during a night, the same pool was thronged with very young fishes. I can not explain from where they came. The fish is viviparous, but upon dissecting at home some of the biggest, I had caught during the preceding days, I could not find embryos.

That this dry island is not rich in amphibians does not surprise one. Still one amphibian is found, and well Paludicola brachyops, but only since very recent times I was told. Some years ago large quantities of sand from Aruba, the native country of this toad, were imported into Curaçao for the purpose of building oil refining-works at the Schottegat, and with the sand came the toad. From this spot the creature is beginning to radiate over the whole island, which is made possible by the better watersupply on the plantations nowadays. In bygone days only wells were found on the plantations, from which the water had to be drawn up by hand and in this troublesome way it was possible to keep the fruit trees alive during the dry season. But at present most of the plantations have one or

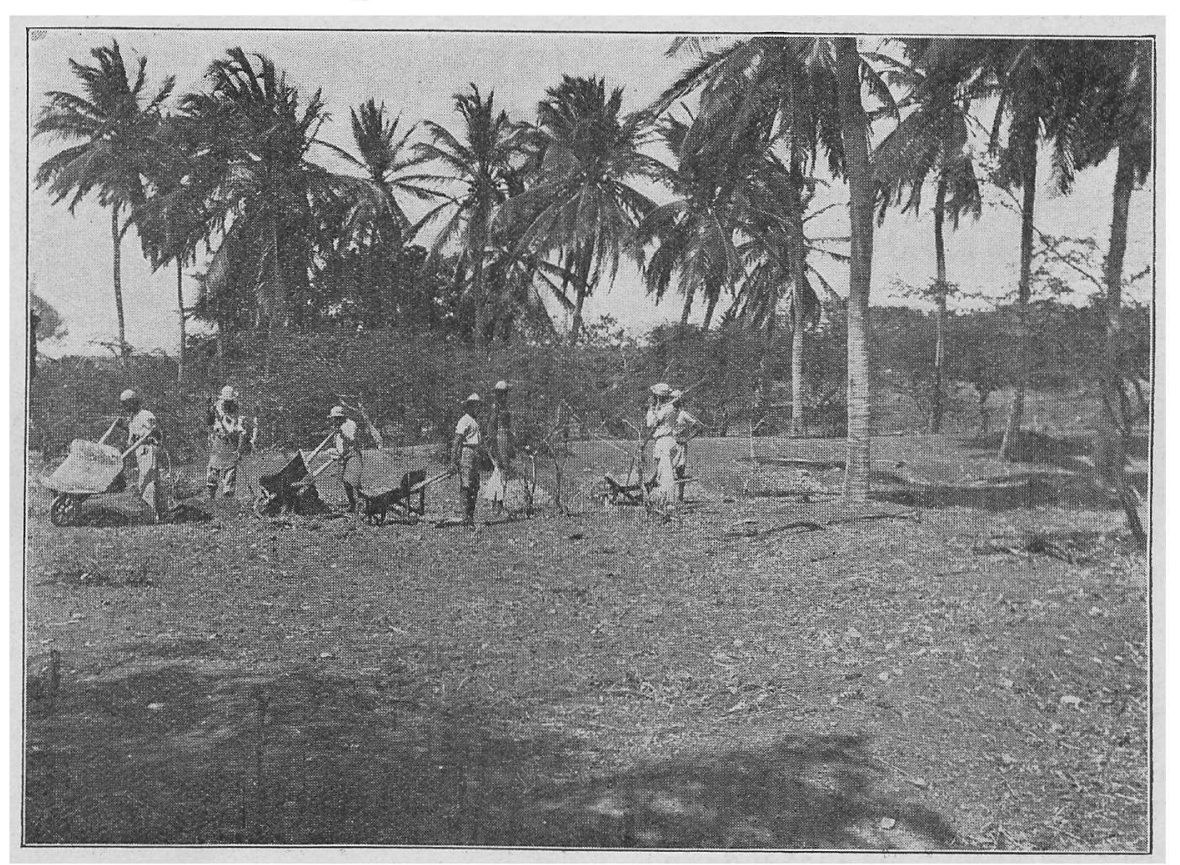

Plantation "Jan Tiel". more wind mills to pump the water into large basins of masonry, whence it is led by canals to the fruit trees. It is easy to understand that favourable life-conditions for an amphibian are created in this way:

The largest part of the plantations is a barren wilderniss covered with leafless shrubs, and only the lowest levels are cultivated. Here well-sized trees are found which, even after a drought of several years, are properly covered with leaves. By an extensive irrigation-system it would not only be possible to improve these gardens, but also to extend them continuously. This may be seen well on the

1) VAN LITH DE JEUDE. On a collection of fishes and reptiles from the West Indies. Notes Leyden Museum. IX. 1887 . 
accompanying picture. The old garden with heavy trees is in the background. Some wind-mills have been erected there to pump the water to the basins on the higher level in the foreground, and this water serves to irrigate the young fruit trees. The young orchard, principally consisting of orangetrees,

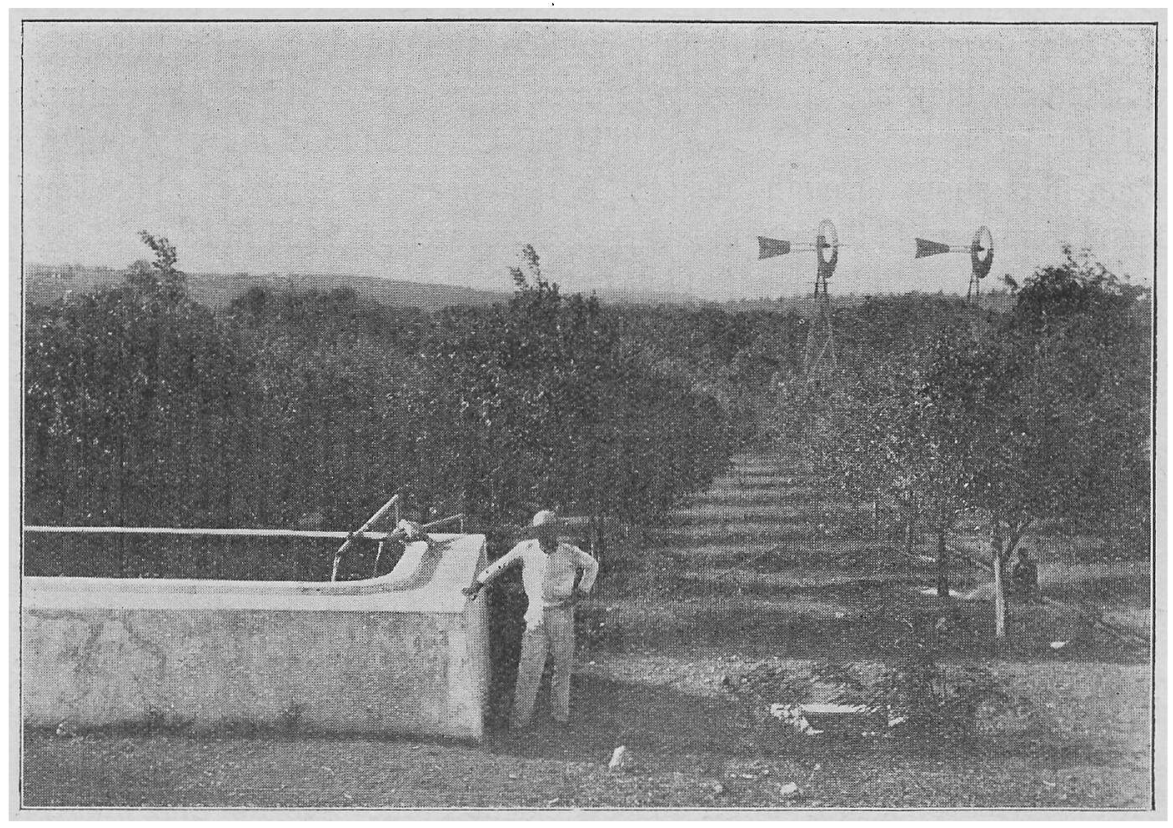

Plantation "Brakke Put Ariba”. was in a splendid condition.

These gardens naturally are the centres of animal life on the island. Different species of lizards, although occuring occasionally all over Curaçao, abound in the gardens. Nearly every trunk shelters one or more specimens of Anolis lineatus, rather slow creatures which may be easily slain with a stick. Different Geckonids will hide themselves in the holes and clefts of the trees during daytime. Among the dry leaves on the ground a charming, little lizard, Gymnophthalmus quadrilineatus, the colebra di mispel of the natives, is quite abundant. It comes out only during the hottest part of the day. This little fanimal is not very quick of movements and easily caught with the hand. But it is necessary for one to be very quick of eye, for the yellow bands, running from head to tail on its dark back and sides, make the lizard very inconspicuous and, therefore, easily lost sight of between the leaves.

Of course, as these lizards are not very conspicuous, it is necessary to look for them in order to see them. Quite the opposite is the case with the lizards that populate the barren regions of the island. These belong to two species only of the genus Cnemidophorus. They are not at all nocturnal creatures, prefering the fierce, burning sunshine. Everywhere one goes they dash away for shelter between the cactuses or under stones and rocks, making it very difficult to seize them. The smaller specimens that hide in small holes, may be dug up or hewn out sometimes. But it would have been impossible for

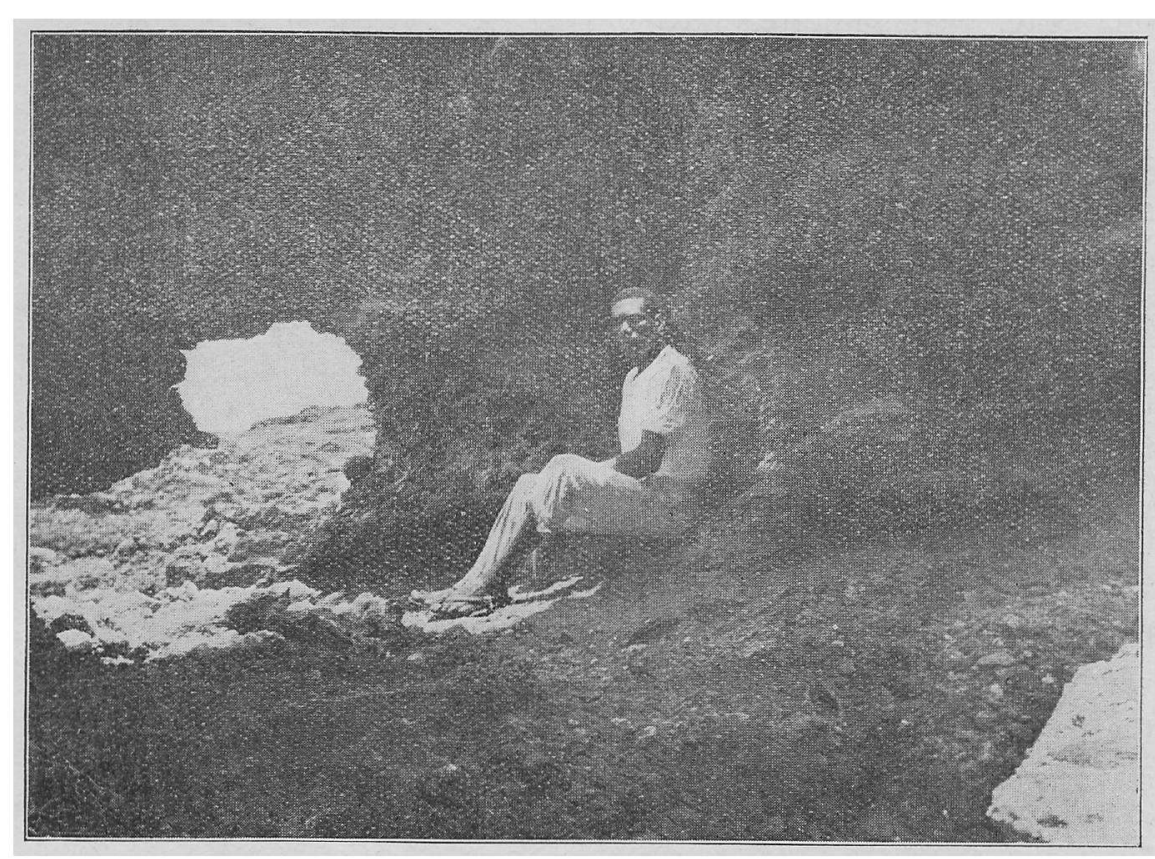

Celestine Reina, between the rocks behind the Quarantine Station.

me to catch the bigger specimens without the help of my native boy CELESTINE ReINA. He was a crack stone shot and thus procured ime some of these quick lizards. He once hit an iguana while running at full speed towards the fleeing animal. Once we saw an iguana slip away into a hole. Celestine quickly gathered some dry twigs, put these into the mouth of the hole and set them on fire. As the halfburned twigs fell down into the hole, the terrified iguana could not get away quick enough but that Celestine got hold of it. Indeed I owe numerous specimens of my collection to him. He was thoroughly acquainted 
with the local Fauna and had a remarkable memory for what I had collected already. He accompanied me on all my excursions and used to call my attention to a crab or some other creature; I had not yet met with. And whenever I was collecting something special, Celestine would continue to search for himself, and often came back with a rather good bag. At first conversation went on rather haltingly but such improved very soon and when I asked Celestine something in the few words of Papiamento, the native language, I knew, I got an answer in equally good Dutch.

On Curaçao also two species of snakes occur; I only could get hold of one, Liophis triscalis. Whether a rattlesnake too may be found, as mentioned by MS. DE ROOY ${ }^{1}$ ) in her account of the reptiles of Curaçao, seems at least very doubtful to me. The natives told me that two different snakes could be found on the island; they also knew that a rattlesnake occurs on Aruba. If this venomous animal did occur on Curaçao too, the negroes on the plantations certainly should have known it and told me so.

As previously explained I did not collect birds. In 1908 and 1909 Dr. DEARBorn made a good collection of birds of Curaçao which have been described bij C. B. CORY ${ }^{2}$ ). In this article 39 different species of birds are mentioned, most of which were collected by Dr. DEARBORN, and the balance by Benedict and NYe, the naturalists of the "Albatros", NEervoort van DE POLL, and especially by Peters and Hartert. However as all these collectors remained on the island only for a few days I believe that the avifauna of Curaçao has not been exhausted.

Dr. DEARBORN also collected a great number of bats belonging to two different species Mormoops megalophylla intermedia and Phodotes tumidirostris. They inhabit the caves of the island in great

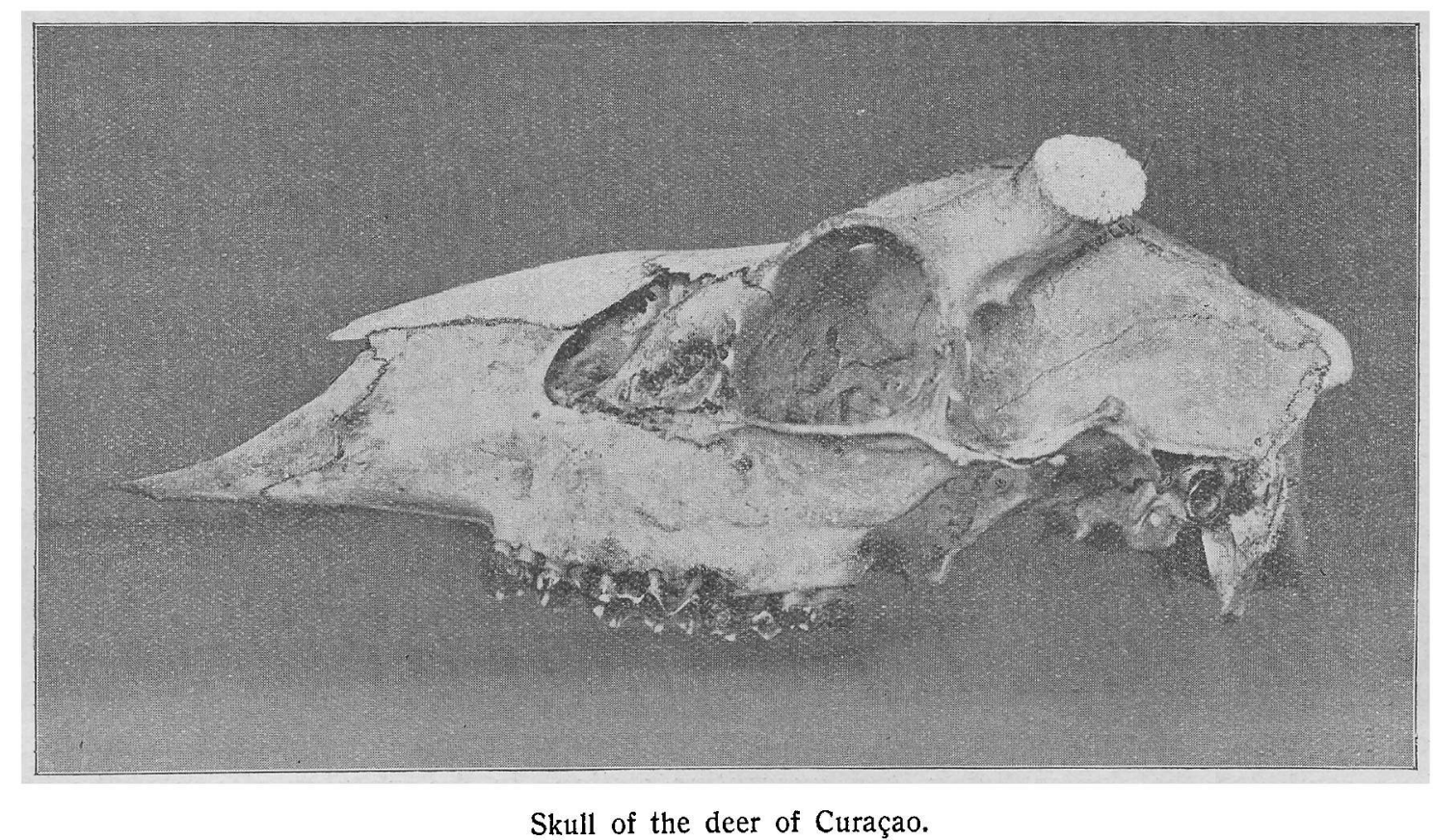

numbers, especially the cave of Hato. A third species Myotis nigricans was collected by me at fort Beekenburg near Caracas Bay. A rabbit Sylvilagas nigronuchalis occurs rather numerous on the island, though not in such numbers as to harm the plantations to any appreciable extent. I tried in vain for a long time to get hold of some. As offering] rewards did not help and these rabbits were too shy and wary of venturing within reach of Celestine's missiles, I had given up all hope, when the last week of my stay on the island I discovered an old fowling-piece and a short hunt furnished me with two specimens.

From a zoological point of view the most important mammal of Curaçao is undoubtedly the deer. It is very curious that the presence of this big mammal on this densely populated and often

1) Nelly DE Rooy. Reptiles and amphibians of Curaçao. Bijdragen tot de Dierkunde. XXII. 1922.

2) C. B. Cory. The birds : of the leeward Islands, Caribbean Sea. Field Mus. Nat. Hist. Ornithological Series. Vol. I. 1909 . 
visited island should have been up till now really unknown in the zoological literature. Only Simons casually mentions it in his "Beschrijving van het eiland Curaçoa": "Cervus capreolus, Binaar, de reebok, is inheemsch". (C. capreotus, Binaar (nom. ind.), the roebuck is indigenous), while also PETERS ${ }^{1}$ ) writes that he was told that a deer occurs on the island, especially on Mount St. Christoffel.: Very probably. we are dealing with Odocoileus margaritae, a deer described by OSGOOD ${ }^{2}$ ) and which occurs on the island Margarita near the coast of Venezuela. At least the most striking feature of Odocoileus margaritae, the abruptly elevated braincase, is also a distinctive character of the Curaçaoan deer. As regards dimensions of skull, the Curaçaoan deer stands about halfway between $O$. margaritae and O. gymnotis, the latter of Venezuela. Years ago the deer was spread over the whole island, I was told, but it now only occurs on and near Mount St. Christoffel in the western part, as also on the plantation "Fuik" at the eastern extremity of the island. Mr. R. J. Muskus, the owner of the plantation "Knip", in which Mnt. St. Christoffel is situated, was very interested in the deer. I am very grateful to him for his kind assistance in my attempt to shoot a specimen. To my great regret the attempt failed; looking intently to the left, whence a deer had been signalled, it passed us on the right. I saw it but at too great a distance for a succesful shot. Mr. Muskus was, however, so kind as to present me with the skin and antlers of a deer he had shot on a previous occasion, and later on he sent a skin and a whole skeleton to the zoological Museum of Amsterdam. He estimates the total number of deer, still existing on Curaçao, at 150, most of which live on Mnt. St. Christoffel. But this number is greatly dependent upon the rainfall. In dry years the food is scarce and the number of deer diminishes. But when much rain has fallen, food is abundant and the animals will propagate and their number may increase rapidly. Often young calves are captured by the negroes. It is to be sincerily hoped that the deer will not become extinct; for the present they are quite safe under the care of Mr. MUSKus who is a good sportsman.

As already said the principal reason for my stay on Curaçao was the study and collecting of the seafauna. Immediatly upon my arrival it was pointed out to me, that the old Quarantine Station near Caracas Bay would be the most suitable place for me. The then guvernor of Curaçao, H. Exc. O. L. Helfrich, at once complied with my request to be allowed to take up quarters at the Quarantine Station. Also Celestine Reina, the servant connected with the Station, was assigned to me. It is my pleasant duty to cordially thank His Excellency for all kindness and assistance shown to me during my stay on the island. A word of thank is also due to the chiefs and other officers of the various departments, notably to those of the departments of Agriculture, Health and of Public Works. Finally, I am greatly indepted to Mr. and Mrs. MENKMAN, in whose hospitable house I so often enjoyed a day of rest and sociability after a week of hard work in the solitude. They have greatly contributed that I now look back with pleasure on the two months I spent on Curaçao.

To live in a quarantine station, must sound rather disagreeable, but it was not half so bad as it would seem. A new station has been erected near Willemstad, and the old one at Caracas Bay was only used for yellow fever, which desease, however, had not occurred for the last twenty years. Only once I was reminded that I was living in a quarantine station. In the morning of one of the first days of my residence there, I noticed that the whole of my face was covered with big blisters. I went at once to Mr. LAMP, the guardian of the station, to ask him what malady had attacked me. He only laughed and explained that I must have gone through the manzanillas. "This is a shrub, Hippomane mancinella, an Euphorbiacee, very abundant on the island, with a venomous chyle. I promptly had the dangerous shrub shown to me and afterwards took good care not to come in contact with it again.

For my purpose the Quarantine Station was ideally situated. This large complex of buildings would be admirably fitted for a permanent zoological station, as Curaçao is within easy reach as well of Europe as also of the United States. A great variety of strand formations occurs in its immediate vicinity; a calm sea here and a heavy surf a short distance of. Clear water and sand or a rocky shore on one side of the road, troubled water and a muddy bottom on the other. First I shall mention the

1) E. Peters. Die Vögel Curaçaos. Canabis Journ. f. Orn. 1892.

2) W. H. OsGood. Mammals from the coast and islands of Northern South America. Field Mus. Nat. Hist. Zool. Ser. Vol. X. 1910. 
Caracas Bay, a rather deep and wide bay opening to the Caribbean Sea and filled with clear, blue Ocean water. Sheltered against the heavy N: E. trade-wind by the Cabrietenberg and the rocks on which the station is built, its water is always calm, scarcely ruffled, as may be seen on the picture of the "Grenadiersmuts". A jungle of mangroves lines the shore of the Western and deepest part of the bay. Here are also many little pools more or less separated from the sea. Some of these pools have a depth of several metres, but the majority are so shallow, as to be drained during low tide, and that means that they are very shallow, as the difference between high and low tide is a foot at most. These mangrove-lined pools are a picture of rest which is still entranced by the numerous, bright-hued jellyfishes, belonging to a new species of Cassiopea, described by. STIASNY ${ }^{1}$ ). These creatures lie with their back resting on the mud. I never saw these jellyfishes swimming, except when I fished some out and put them back into the water. They always lie with their moutharms widely spread.

The larger part of the shore is just a sandy beach, dotted here and there with stones and rocks. Also the bottom of Caracas Bay consists largely of sand, at least as far as I could see. A continuous reef is not to be met with here. The coral colonies lie widely scattered on the bottom. Especially Orbicella annularis occurs here in big colonies, forming large regular spheres with a diameter up to one metre; some have a smooth surface, while others are cut by deep fissures. Below the five metre

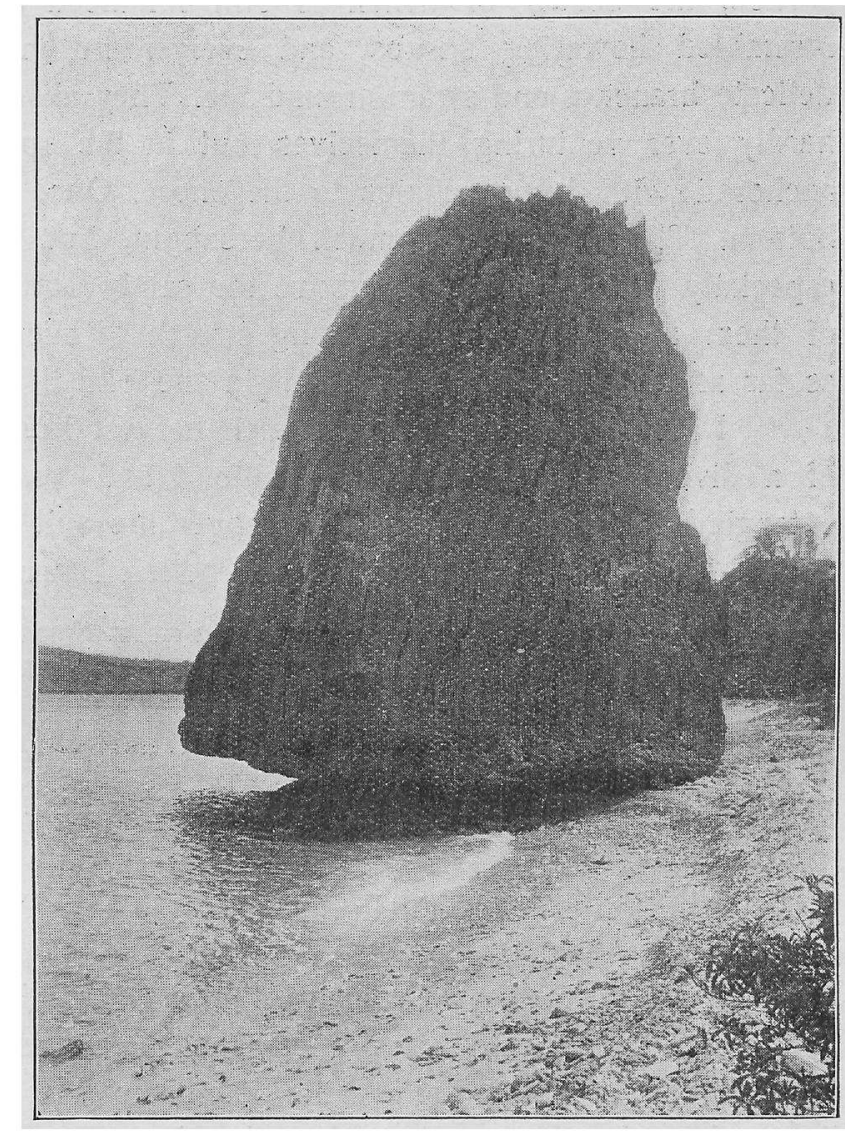

"Grenadiersmuts" on the shore of Caracas Bay.

line Madrepora muricata predominates. Large densely ramose colonies, some of which attain a height of 1,5 metre, lie scattered everywhere or packed together, forming small forests of some tens square metres. These colonies lie loose on the sand, even large ones could be moved with a hook, but they would readily break up, whenever I tried to fish them in this way. Some smaller colonies were hunted up for me and these were gotten safely in the boat.

The Eastern part of the Caracas Bay, i. e. near the Quarantine Station, has a rocky shore; also the sea bottom here consists largely of rocks. As a matter of course the Fauna is here most luxuriant. Large parts of the rock are covered with social anemones, belonging to the Zoanthacea, reaching above the water surface as far as they are within reach of the occasional, feeble waves. Immediately under the surface large colonies of Madrepora palmata flourish, some of which reach a diameter of several metres. From the surface till as far as my eye could penetrate the depth of the clear water, a continuous forest of different gorgonids covered the bottom. Among the sponges a Hircinide was especially conspicuous. This sponge consists of a number of bifurcated tubes, nearly six millimeters wide and one metre high. The orifice at the top of the tube is partly closed by a diaphragma. One big colony was hunted up for me, and out this two small fishes appeared, which have been described by Dr. METzELAAR ${ }^{2}$ ) as a new species of the genus Gobiosoma. It is quite possible that this fish uses the tubes of this sponge as a safe retreat. Though I looked for numerous similar hiding places this remained the only instance that I caught the fish, and well two specimens at a time.

1) G. Stiasny. Ueber einige von Dr. C. J. v. D. HoRst bei Curaçao gesammelte Medusen. See p. 83.

2) J. MetzelaAR. On a collection of $m$ arine fishes from the lessér Antilles. Bijdragen tot de Dierkunde. XXII. 1922. 
It is a splendid sight to look through the glass bottom of a little box on this mixed variety of creatures, but I only could fully enjoy it, when the Chief of Public Works put a diving suit at my disposal. Many a time I made the most of it. Words fail to describe the splendour of such a submarine garden, the beauty of which is still enhanced by the soft, tempered light. The man-high gorgonids resembled flowering shrubs; and everywhere multi-coloured fishes darted in and out between the delicate branches and swam around me. They always remain in the vicinity of the gorgonids and corals, hardly ever venturing themselves out in the open water. There is a buoy in Caracas Bay which is anchored with heavy chains to the shore. Once I came across one of those chains, lying on a sandy bottom. There grew not much hereabout, but the chain itself was completely covered with corals, especially Millepora. Whilst above the sandy bottom hardly a fish was to be seen, it simply swarmed of them along the chain, a long stretch of ever changing colours and hues extended over the plain as far as I could see, losing itself in the bluish distance.

I never brought home a rich harvest from such a diving expedition. Collecting with the help of a diver is by far more profitable. I had continually to pay attention, that the airtube did not get entangled between the corals; moreover the suit itself impedes much moving. With some more experience, however, it might have gone better. Later on I learned that it was much more practical to dive without the suit, with the helmet only, and this is also by far less dangerous, because the helmet may be easily taken off thus enabling a man to swimm to the surface. Nevertheless, I collected many corals and gorgonids in this way and, indeed, it would be extremily difficult to get hold of the large colonies of gorgonids in another way. They are so firmly anchored to the rock, that it took me surely ten minutes to loosen them with hammer and chisel.

The rocks behind the Quarantine Station contain some small pools, the bottom of which consists partly of bare rock, partly of rock covered with a thin layer of sand. On the rocks in these pools small green algae grew. While I was looking here for crabs, fishes, anemones, etc. I discovered between the threads of the algae numerous specimens of an acornworm which later on proved to be Ptychodera bahamensis. It was fairly easy in this way to collect quite a number of entire specimens; usually the extremely fragile Enteropneusts break into fragments. I had just to scratch some algae from the rock and examine them in a bassin under water. So this Enteropneust does not live in the bottom as most others do, it lives between algae, but it is enclosed in a mucous sheeth sprikled with sand granules. I often found the same species under stones near the shore.

Whilst Caracas Bay is very calm except for the unapproachable Western part, where heavy waves leap high against the steep rock wall, there is a rather heavy surf in the less sheltered Spanish Bay. Here I could study very well the leading part played in the formation of limestone by the incrusting Corallinaceae, i. e. algae that secrete and deposite carbonate of lime in their cell membranes. When quickly, between two breakers, I broke off a prominent piece of rock with hammer or shoe, I found this to consist largely of fragments of corals with an admixture of shells, the whole bound together by the all overgrowing algae. In this continually growing part of the rock the bond is rather weak yet, and the pieces may often be broken up by force of ones hands. As a matter of course the surface is very rough. with plenty of holes and gaps and sharp, protruding points and ridges. The older stone has the same aspect, and this is the case with the limestone near the shore as also with that found on the top of the Cabrietenberg.

In this rough water other animals occur than in the calm Caracas Bay. Numerous seaurchins lie bored into the rock like fritters in a pan. Every little basin in the rock contains specimens of Holothuria glaberrima, a seacucumber, firmly attached with the numerous sucking feet. Among the snails especially the Fissurella's and Patella's are frequent.

At the Northern shore of the island, which is fully exposed to the strong N.E. tradewind, the surf is by far heavier. Continually the heavy breakers will leap over the five metre high rock wall. There collecting is only possible in the few small bays, like the Boca labadera, and even that only with some prudence and at the cost of a wet suit.

A locality, very favourable for the zoologist, is also the Spanish Port, the channel, connecting the Spanish Water with the Spanish Bay and the Caribbean Sea. Here are some areas, where the bottom consists of a level rock, sloping down very gently. This rock is at a distance of a few metres 
from the shore, covered with a layer of sand, about a foot thick. This is the most favourable locality to collect animals living in the sand, and well for the simple reason that they cannot withdraw into the depth or between stones. It is only necessary to scoop the sand from the rock and to sieve it in order to capture numerous gephyreans, enteropneusts, worms, mussels, crabs etc. My attention

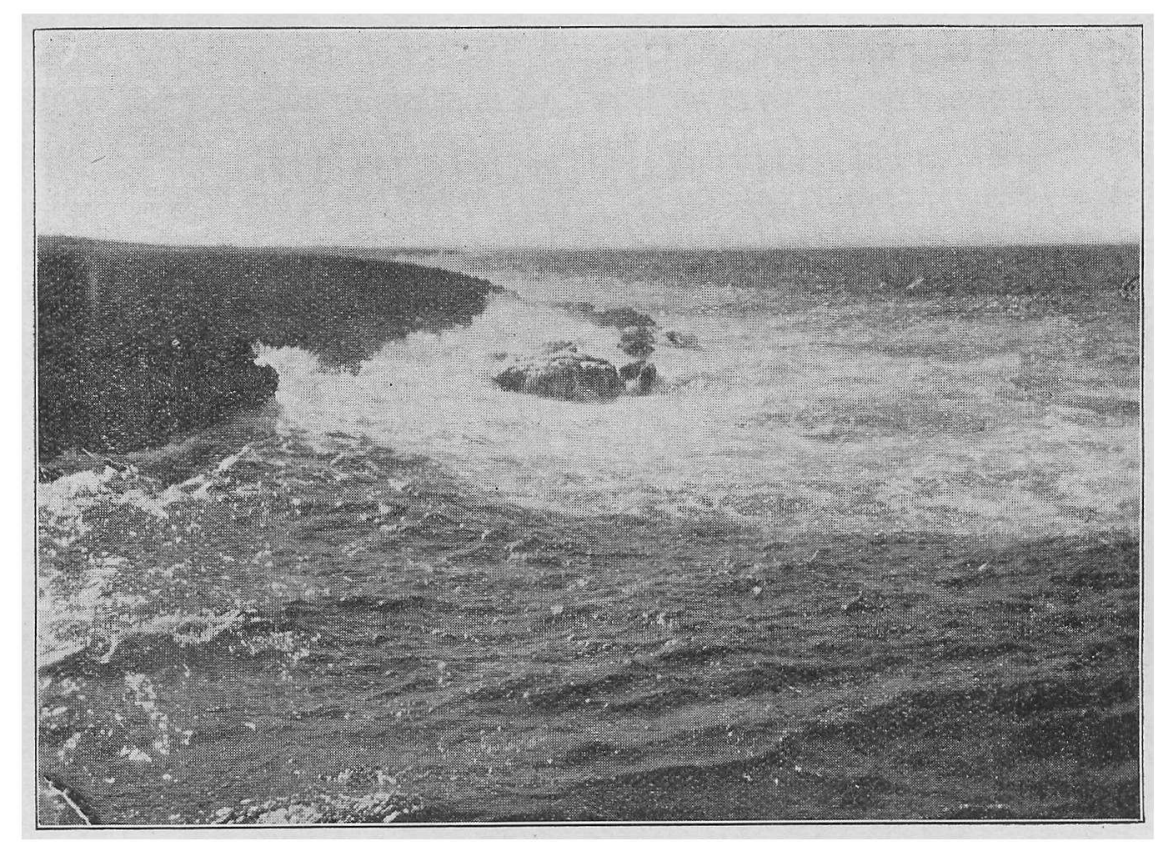

Heavy surf at the North coast of Curaçao.

was called to the suitability of such a locality by Prof. J. STANLEy Gardiner who in Chapter III of „Science of the Sea" gives many useful hints to the tropical shore collector.

There is a great difference between the Caracas Bay and the Spanish Water, though they are

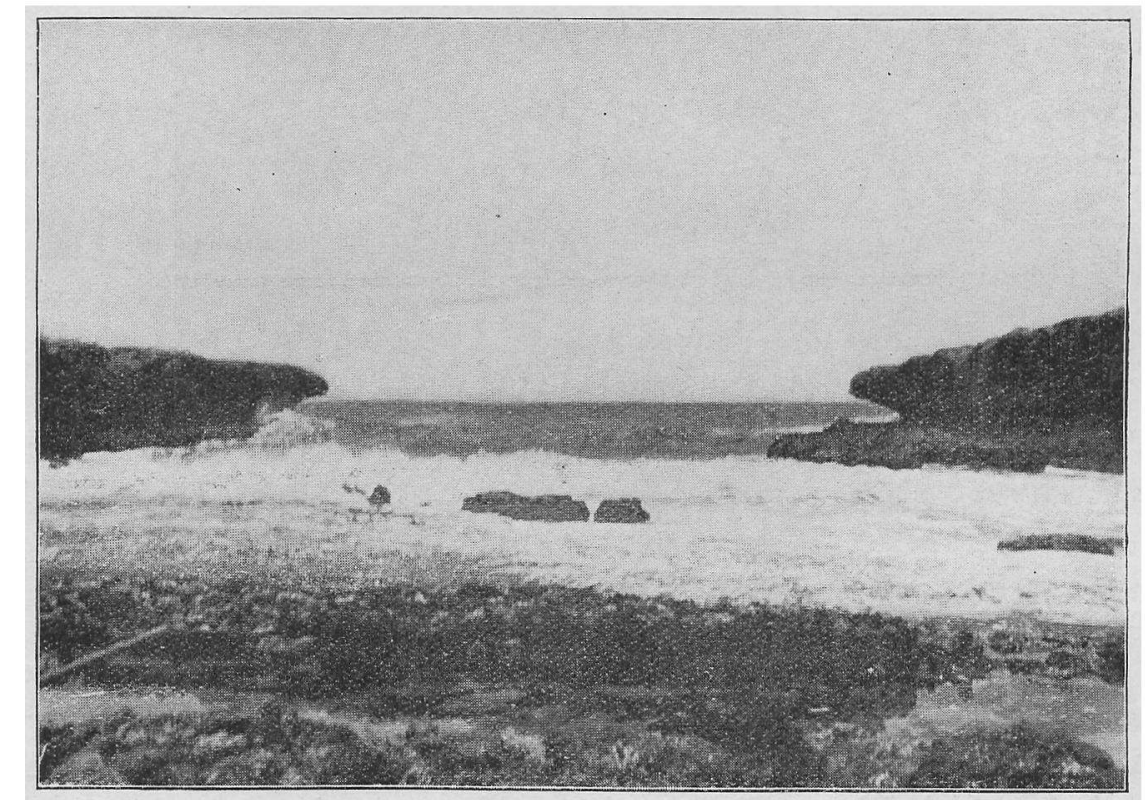

Boca labadera.

separated from each other by a narrow neck of land, at some places measuring across only some tens of metres. The Spanish Water is like an inland sea, remainder as it is of the lagoon, dating from the long past times when Curaçao was an atoll. It has many bays and some small islands and stands only in communication with the Caribbean Sea by the rather narrow Spanish Port. As the tides are 
of small importance, the renewal of the water is not great, though it is sufficient to prevent any considerable in- or decrease in the salinity during dry or rainy times resp.. Compared with the clear blue ocean water of Caracas Bay, the Spanish Water is muddy, I could not look deeper than two metres here. The bottom too consists largely of mud mixed with stones. As a matter of course this difference has a great influence on the animal life. I looked in vain for Gorgonids in the Spanish Water, although they were so abundant in Caracas Bay. Sponges occur in great numbers in both localities, but the species that live in Caracas Bay, are missing in the Spanish Water and the reverse is also true, and for which I beg to refer to the article of Dr. ARndT on the sponges, collected by me. Very striking was also the difference in the corals which thrive in these areas. As written before many big colonies, both of Madrepora palmata and of Madrepora muricata, flourish in the Caracas Bay. After prolonged searching I found in the Spanish Water a few very poor, incrusting colonies of Madrepora, a square decimetre large at most, to identify the species of which was not possible to me. Also Orbicella annularis is wanting. Of Siderastraea siderea however, many, several metres large

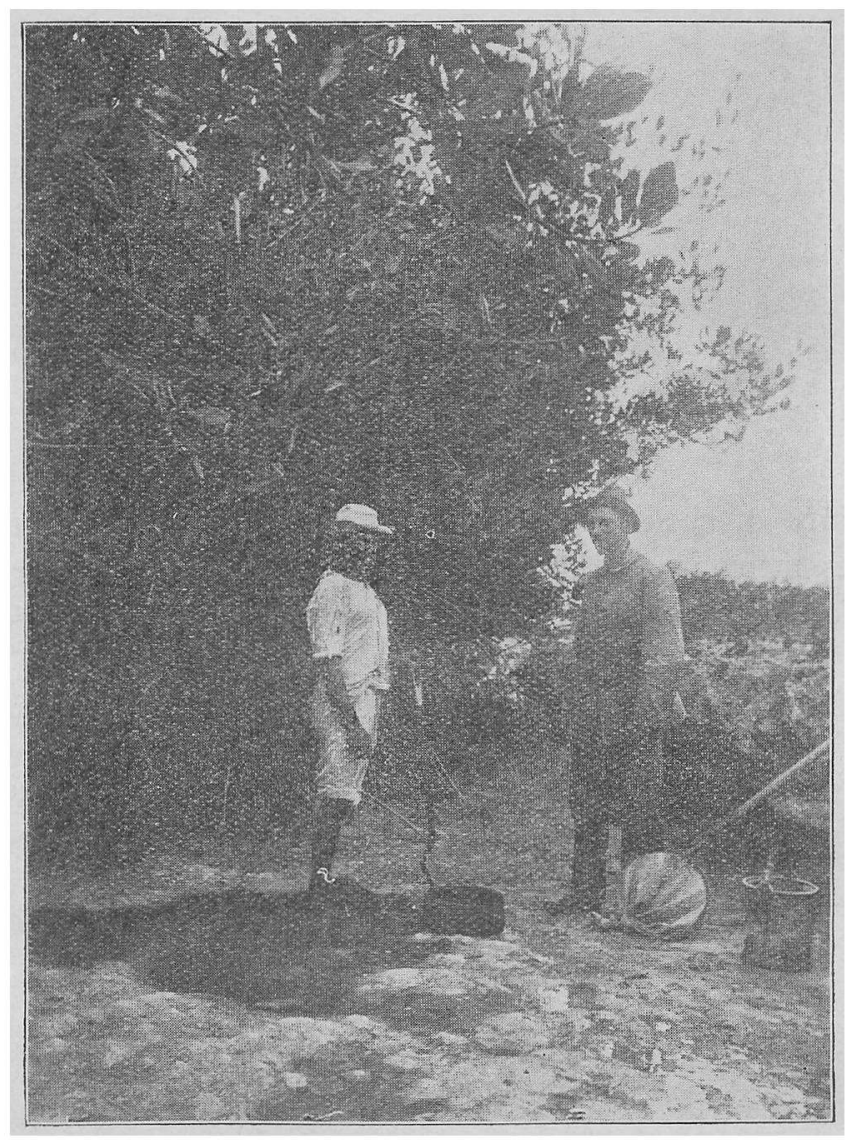

Spanish Port, a fine locality for collecting burrowing animals.

colonies are to be found, and this species again is rare in Caracas Bay. This quite corresponds with what VAUGHAN ${ }^{1}$ ) writes about the presence of these corals. That some corals are very sensitive to muddy water, and others not at all, has been experimentaly controlled by MAYER ${ }^{2}$ ), and the results of his research also quite correspond with the occurence of the different species of corals in the Caracas Bay and the Spanish Water. The massive Porites astreoides is very frequent in the Caracas Bay but not in the Spanish Water, while just the reverse is the case with the branched Porites furcata. It occurs in great numbers in the Spanish Port, but remains small, attaining a height of one decimetre

1) T. WAyLand VAughan. Studies of the geology and of the Madreporaria of the Bahamas and of Southern Florida. Carn. Inst. Wash. Year Book N $N^{0} 11.1912$

2) A. G. MAYER. Ecology of the Murray Island coral reef. Papers Dept. Mar. Biol. Carnegie Inst. Wash. Vol. IX. 1918. 
at most. In the Spanish Water this species is very common, and the colonies generally have a height of $30 \mathrm{~cm}$.

I have examined many of these colonies of Porites furcata, not for the coral itself, but for the numerous animals that seek shelter between its closely packed branches. And such happened especially in the Spanish Water, the colonies in the Caracas Bay and the Spanish Port harboured only a few animals. The creatures $I$ found in these Porites colonies comprised ophiurans and worms in great numbers and of different species, further fishes, crabs, shrimps, nemerteans, ascidians, chitons, snails, lamellibranchiates and many others.

The roots of the mangroves that fringe the Spanish Water are also much frequented by many creatures. Amongst the latter were large red sponges which had fastened to the roots, and clusters of black ascidians, others again were quite covered with oysters and serpulids, corals and anemones.

It is very remarkable that one group of animals, the starfishes, otherwise so common at all coasts, is nearly totally wanting here, although the conditions of life seem to be quite favourable to them. As I missed them pretty soon, I particularly looked for them. I found only a few, one or two specimens a day, hiding between and under the stones near the shore. Most of them were very small specimens, and which I identified with the help of the indications, kindly sent me by Prof. DöDERLEIN, as Linckia guildingi and the allied Ophidiaster guildingi. At other times starfishes must occur in great numbers, at least, the fishermen to whom I showed a figure of Astropecten knew the animals very well, and told me that they otherwise were quite common in the Spanish Water. However I am not the only one who did not find starfishes, for NUTTiNG ${ }^{3}$ ) says that during the Barbados-Antigua Expedition almost no starfishes were found near the said islands, while also only Linckia guildingi occured in greater number at Barbados. What the cause might be of the absence of these animals, I don't know, and neither does Prof. DöDerlein, to whom I wrote about it. Also NuTTing gives no satisfactory explanation.

I am very sorry that I hardly could dredge, for having only a small rowing boat at my disposition, dredging at any great depth was, of course, out of the question. Often I tried to bring the dredge out with the boat and then to pull it to the shore, but also this did not succeed. Immediately, after I began to pull the rope, the dredge would get entangled in the corals or stones. Only at some shallow spots in the Spanish Port I could dredge, but the seaurchins that I captured in this way, I could have easely picked up.

As said before Dr. BoEKE, when on Curaçao in 1905, made a large collection of fishes. That's why I did not take much trouble in collecting fishes myself. I only paid special attention to the fishes that occured in coral colonies, or sponges, between stones and in similar localities. Of course, these are all small animals without any market value. But when I could lay hands on food fishes, I did not neglect to preserve also these. And I often had a good chance to do so. Hipolito LAMP, the guardian of the Quarantine Station, was an excellent fisherman. He used to spend a part of his leisure-hours with fishing. He always laid out a number of traps, made of chicken fence wire, in the Caracas Bay. They were simply thrown into the sea but always near one of the large colonies of Madrepora muricata and next morning he pulled them up by the aid of a hook and rope. The men were always very cautious when a Muraena was caught, and not without reason, as will be clear from the fact that these rapacious, sharptoothed animals are wont to hold a goodly cleaning among their fellowprisoners. It was not necessary for me to be present, though I, of course," often was. Mr. LAMP did not only know all fishes very well, but he knew also exactly, better than I did, whether or not I already had collected a certain fish, and, of course, all fishes, new to my collection, were preserved.

Often we fished with the seine at a place behind the Quarantine Station and where all corals and stones had been removed for that purpose. In that way we caught a great number of fishes, indeed, but the variety was by far smaller than in the traps. The catch consisted largely of flying fish, Hemiramphus, and some garfish. During the last days of April no more Hemiramphus were caught more, and the fishermen came home almost empty handed, but on April $30^{\text {th }}$ they returned with a boat full of a species of fish that I had not seen before. It was. a dark blue fish with a golden band around the head, about as long as a herring, but much thicker. This fish, known under the name of

3) C. C. Nutting. Barbados-Antigua Expedition. University of Iowa Studies. Studies in Natural History. Vol. ViII. Number 3. 1919. 
Inermia vittata, occurs in large shoals at Curaçao at irregular times but mostly during the winter months. Sometimes they are not seen for several years. They appear suddenly and so they disappear again. Next day only a few were still caught and then it was finished. According to Mr. LAMP these fishes come from great depth. That they are a puzzle, safe to science - they were only once captured by a scientific man before - also to the fishermen is clear from the fact that they are known on Curaçao under the name of "Onbekend" i. e. "Unknown”.

Mr. LAMP did for me more than fishing, he was the only fisherman near Caracas Bay who could dive, whereas at other places of the island, for instance near Westpunt, all fishermen can swim and dive like otters. He has hunted up for me numerous corals and sponges out of the Caracas Bay. Moreover he and his family cared well my material wants and I am grateful to him, his wife and ANTOINETTE, one of his many daughters, for all they did for me. I shall always remember with pleasure the two. months I spent in their midst at the Quarantine Station near Caracas-bay.

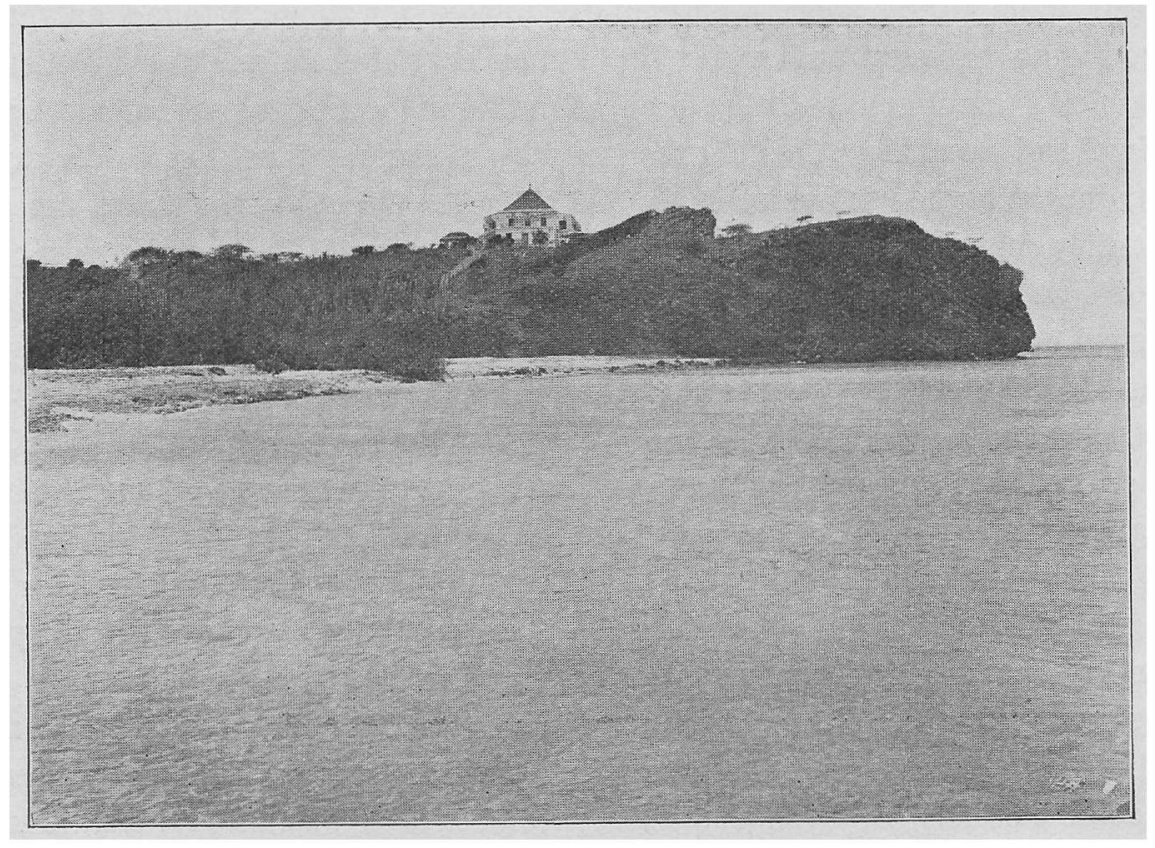

The Quarantine Station near Caracas bay. 


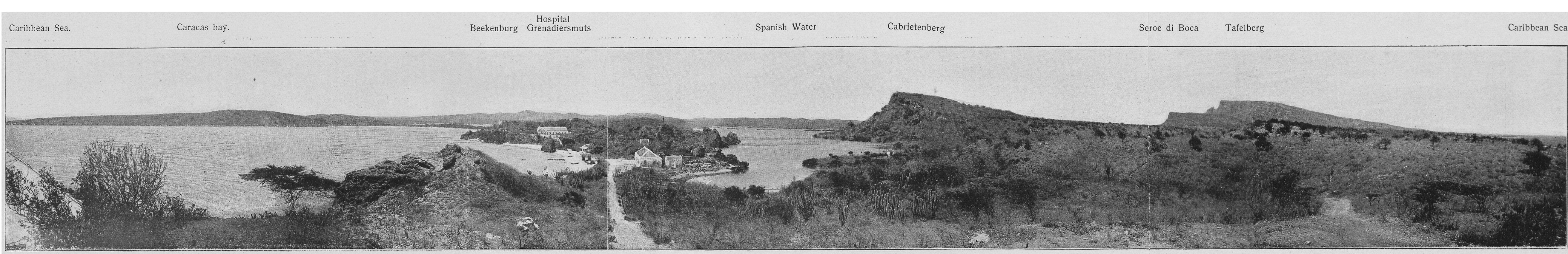




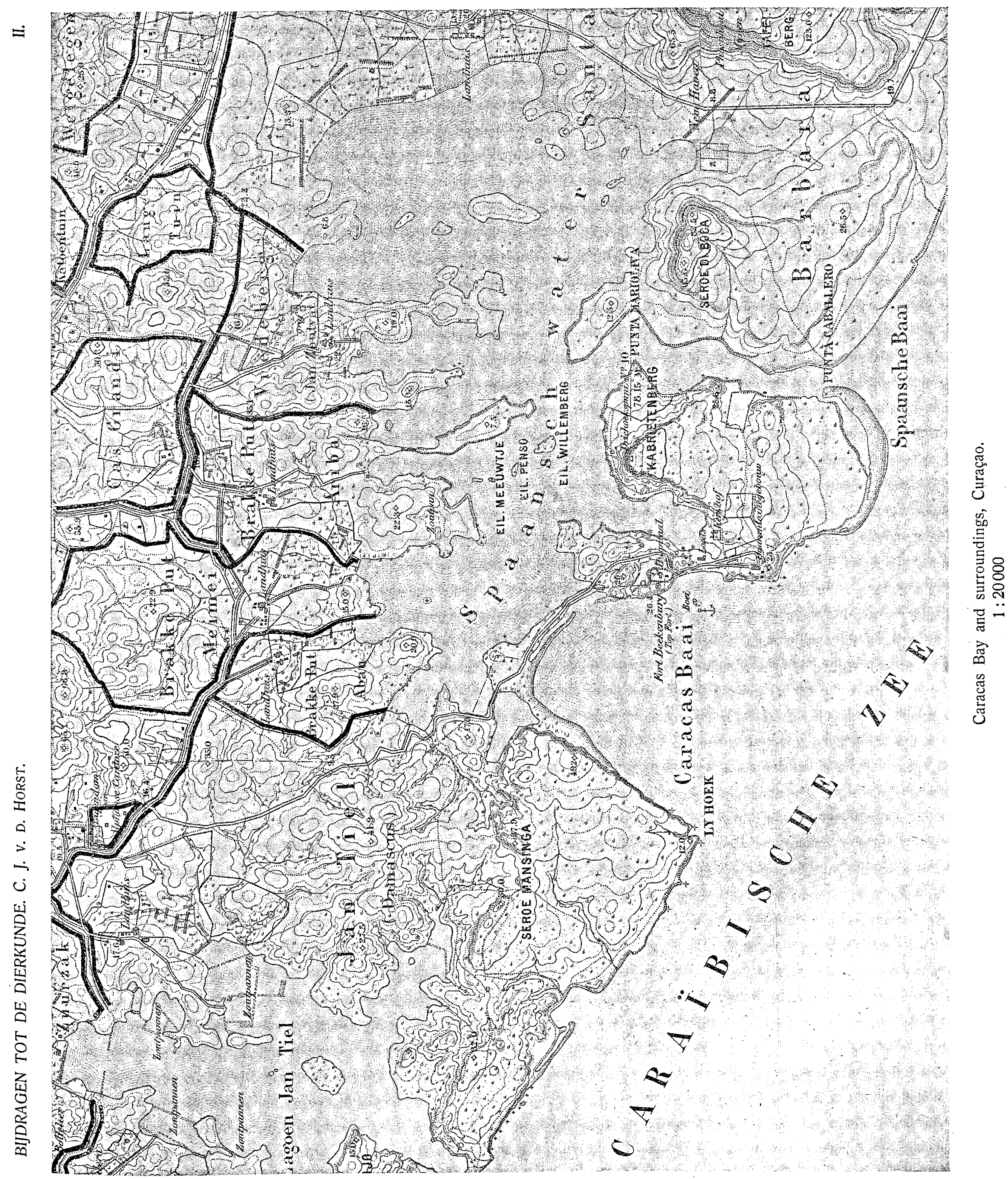

